\title{
HIV control through a single nucleotide on the HLA-I locus
}

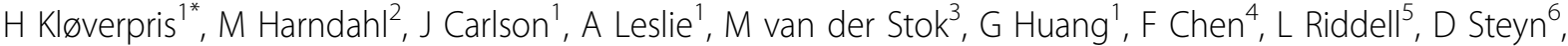

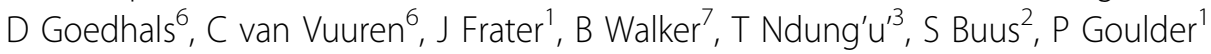

From AIDS Vaccine 2012

Boston, MA, USA. 9-12 September 2012

\section{Background}

In correlative studies HLA class I type is consistently found to have the strongest impact on HIV disease progression. However, the exact mechanism involved is complicated by several factors; many alleles are ligands for NK cells as well as CD8 T-cells, and strong linkage disequilibrium between Class I alleles makes it difficult to distinguish the effect of individual alleles from other HLAs or from other important loci found on the HLA haplotype, such as the recently described -35 SNP.

\section{Methods}

Here we study two recently diverged HLA alleles, $B * 4201$ and $B * 4202$, which only differ by a single amino acid. Crucially, they occur primarily on identical Class I haplotypes and do not act as NK cell ligands. Therefore, they represent a unique opportunity to study the impact of a single HLA allele on HIV immune control not confounded by other genetic factors in a large outbred cohort $(n=2,093)$ of C-clade infected individuals.

\section{Results}

Here we show that the amino acid change in position 9 of the HLA-B molecule, is critical for peptide binding and significantly alters the Gag CTL epitopes targeted $\left(\mathrm{P}=2 \times 10^{-} 10\right)$, measured both directly ex-vivo by ELISPOT and indirectly through CTL escape mutation $\left(\mathrm{P}=2 \times 10^{-8}\right)$. Strikingly, HLA-B 4201 is associated with significantly lower viral load setpoint than HLA-B*4202 $(\mathrm{P}=0.02)$.

'University of Oxford, Oxford, UK

Full list of author information is available at the end of the article

\section{Conclusion}

This naturally controlled experiment represents perhaps the clearest demonstration of the direct impact of particular HIV Gag specific CTL on disease control.

\section{Author details}

'University of Oxford, Oxford, UK. ${ }^{2}$ University of Copenhagen, Copenhagen, Denmark. ${ }^{3}$ University of KwaZulu-Natal, South Africa. ${ }^{4}$ Royal Berkshire Hospital, Reading, UK. ${ }^{5}$ Northampton General Hospital, UK. ${ }^{6}$ University of Free State, Bloemfontein, South Africa. ${ }^{7}$ Ragon Institute of MGH, MIT and Harvard, Boston, USA.

Published: 13 September 2012

\section{doi:10.1186/1742-4690-9-S2-047}

Cite this article as: Kløverpris et al:: HIV control through a single nucleotide on the HLA-I locus. Retrovirology 2012 9(Suppl 2):O47.

Submit your next manuscript to BioMed Central and take full advantage of:

- Convenient online submission

- Thorough peer review

- No space constraints or color figure charges

- Immediate publication on acceptance

- Inclusion in PubMed, CAS, Scopus and Google Scholar

- Research which is freely available for redistribution

Submit your manuscript at www.biomedcentral.com/submit
Biomed Central

\section{() Biomed Central}

